\title{
Modeling the Effect of Temperature and Wetness on Guignardia Pseudothecium Maturation and Ascospore Release in Citrus Orchards
}

\author{
Paul Fourie, Tian Schutte, Suzel Serfontein, and Fanus Swart
}

First author: Citrus Research International, P.O. Box 2201, Stellenbosch 7602 and Department of Plant Pathology, Stellenbosch University, Private Bag X1, Stellenbosch 7602, South Africa; second author: Citrus Research International, P.O. Box 28, Nelspruit 1200, South Africa; and third and fourth authors: QMS Agri Science, P.O. Box 416, Letsitele 0885, South Africa. Accepted for publication 26 November 2012.

\begin{abstract}
Fourie, P., Schutte, T., Serfontein, S., and Swart, F. 2013. Modeling the effect of temperature and wetness on Guignardia pseudothecium maturation and ascospore release in citrus orchards. Phytopathology 103:281-292.

Ascospores are the most important inoculum source of citrus black spot (CBS), caused by Guignardia citricarpa, but pseudothecium maturation and ascospore release are inadequately studied. Guignardia ascospore trapping and concomitant weather data were obtained for three localities over three seasons (July to March 2006 to 2009) in the Limpopo province of South Africa. Degree-days accumulated until first seasonal ascospore discharge $\left(>10^{\circ} \mathrm{C}\right.$ with 1 July as biofix) (DDtemp), and DDtemp accumulated on rainy (rainfall $>0.1 \mathrm{~mm}$ ) (DDrain) and moist days (vapor

predict onset of ascospore release: a temperature model [Event $=$ $\exp (-\exp (-(-2.725+0.004 \times$ DDtemp $)))]$ and a temperature/moisture model [Event $=\exp (-\exp (-(-3.238+0.008 \times$ DDvpd $+0.004 \times$ DDtemp $0.009 \times$ DDrain $)))]\left(R^{2}=0.608\right.$ and 0.658 , respectively $)$. Both models predicted a delay in pseudothecium maturation in climates with colder winters and springs. A Gompertz equation was also used to predict the proportion of Guignardia ascospores trapped (PAT) per season from DDtemp data accumulated on wet or moist days (DDwet2) from the first seasonal ascospore discharge [PAT $=\exp (-4.096 \times \exp (-0.005 \times$ DDwet2); $\left.R^{2}=0.908\right]$. The PAT model predicted lag phases and 7-day peaks in ascospore release patterns with reasonable accuracy. These models can be used to predict the onset and dynamics of ascospore release in climatically diverse regions.
\end{abstract} pressure deficit $<5 \mathrm{hPa}$ ) (DDvpd) were used in two Gompertz models to
Citrus black spot (CBS), caused by Guignardia citricarpa (anamorph Phyllosticta citricarpa), affects all commercial citrus cultivars. Effective control of CBS is almost entirely dependent on the application of fungicidal sprays at 4- to 6-week intervals during the critical period of infection from mid-spring to mid-summer (October to January in the southern hemisphere) (20,30-32). In similar pathosystems, such as apple scab, caused by Venturia inaequalis $(6,15,27,28)$; pear scab, caused by V. pirina (29); and citrus greasy spot, caused by Mycosphaerella citri $(22,23)$, ascospore release has been studied and modeled on environmental parameters, which allow for better timing of fungicide spray applications than calendar-based spray programs. As with CBS $(10,12,19,20)$, ascospores are considered the most important inoculum source in the epidemiology of these diseases, while conidia are of lesser importance. Research efforts by various groups have progressed considerably in understanding ascocarp formation and maturation and ascospore release of these pathogens. Temperature optima differed between these pathosystems but were similar to those suiting the host. Pseudothecium maturation was dependent on suitable degree-day accumulation during spring, as well as moisture of leaf litter (resulting from rain, dew, or irrigation), and a combination of these parameters yielded the most accurate pseudothecium maturation models (29).

The conditions required for pseudothecium maturation of G. citricarpa in fallen citrus leaves $(10,12,13,19)$ were similar to those reported for $M$. citri. Pseudothecia developed in infected

Corresponding author: P. Fourie; E-mail address: phf@cri.co.za

http://dx.doi.org/10.1094/PHYTO-07-11-0194

(c) 2013 The American Phytopathological Society leaf litter on the orchard floor within 40 to 180 days after leaf drop, depending on the prevailing temperatures and frequency of wetting and drying of leaf litter (12). Periodic wetting and drying of leaves, as well as alternation of temperatures $\left(27\right.$ to $30^{\circ} \mathrm{C}$ during the day and cooler temperatures at night) proved to be optimum conditions for pseudothecium maturation (10). McOnie (19) observed that late-winter conditions had little effect on pseudothecium maturation and, given the fairly uniform onset of ascospore release over 3 years of spore trapping, concluded that climatic data from 1 September to the first date of heavy discharge should be compared. When mean temperatures during this period were closer to the reported optimum of 21 to $28^{\circ} \mathrm{C}(13,37)$, the onset of ascospore release was promoted. On the basis of the wet-dry requirement, McOnie (19) defined an "effective rainy day" (isolated showers of $\geq 5 \mathrm{~mm}=1$ rainy day; showers of $\geq 5 \mathrm{~mm}$ but separated by $<1 \mathrm{~h}$ sunshine $=0.5$ rainy day and observed that, over four seasons, 6 to 6.5 rainy days occurred from 1 September to onset of ascospore release. However, Kiely (10) reported that, in areas with heavy dews, rain was not essential, although its incidence might hasten the maturation period. Conversely, a deleterious effect of constant moisture on fallen leaves was observed $(10,13)$, mostly as a result of rotting of leaves by saprophytic fungi or bacteria. In contrast, very hot weather was not favorable for the early developmental stages of pseudothecium formation and maturation, because too rapid dehydration of leaves often led to the apparent death of latent mycelia (10).

$G$. citricarpa ascospores are reported to be forcibly ejected from mature pseudothecia when moistened by water, and ascospores are released from leaves up to 5 months after removal from trees $(10,19)$. Ascospores are dependent on conversion currents and favorable environmental conditions to reach a suitable host 
substrate, because the maximum vertical distance of ascospore ejection from a pseudothecium is 10 to $12 \mathrm{~mm} \mathrm{(10)} \mathrm{and} \mathrm{the} \mathrm{hori-}$ zontal disease dispersion occurs at distances <24.7 m (34). Kiely (10) trapped ascospores consistently throughout spring, summer, and autumn and noted that their numbers did not appear to correlate with periods of rainfall. Hence, Kiely (10) concluded that dew provided sufficient wetting to initiate ascospore release. Under South African conditions, McOnie $(19,20)$ trapped negligible levels of ascospores during spring, and observed ascospore release peaking from November through January and lower levels in autumn. However, release typically followed rain events and was heaviest during high-rainfall months (19). Ascospore release could not be correlated with flood-irrigation or dew, although McOnie (19) conceded that irrigation was seldom necessary during November to January due to summer rainfall. Unlike $V$. inaequalis (15), Guignardia ascospore release could not be linked to time of day (19).

Environmental conditions required for $G$. citricarpa ascospore germination varied from 15 to $29.5^{\circ} \mathrm{C}$ and 15 to $38 \mathrm{~h}$ of wetness (11). At $25^{\circ} \mathrm{C}$ on detached citrus leaves, McOnie (21) observed peak ascospore germination within $24 \mathrm{~h}$ and appressorium formation within $48 \mathrm{~h}$; this was markedly faster than germination and appressorium formation rates reported by Kiely (10) on potato dextrose agar plates.

Despite the understanding and successful modeling of pseudothecium maturation and ascospore release in similar pathosystems mentioned above, it has not been attempted for G. citricarpa, largely due to the lack of long-term empirical data. Based on an extensive data set, this article describes the climatic variables associated with Guignardia pseudothecium maturation and ascospore release, and describes epidemiological models, similar to those proposed for $V$. pirina (29), that predict onset of ascospore release and seasonal ascospore release patterns.

\section{MATERIALS AND METHODS}

In the Limpopo province of South Africa, several large citrus estates contracted a plant pathology services company (QMS Agri Science, Letsitele, South Africa; www.agriscience.co.za) to conduct Guignardia ascospore trapping and weather monitoring to support CBS management. Using methods similar to those described by Reis et al. (26), Guignardia ascospores were trapped from September through March in three localities-namely, Letaba Oranje $\left(23^{\circ} 48^{\prime} 37.58^{\prime \prime} \mathrm{S}, 30^{\circ} 26^{\prime} 35.74^{\prime \prime} \mathrm{E}\right.$; near Letsitele),

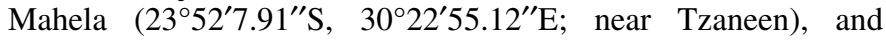
Portsgate $\left(24^{\circ} 22^{\prime} 9.93^{\prime \prime} \mathrm{S}, 30^{\circ} 43^{\prime} 4.08^{\prime \prime} \mathrm{E}\right.$; near Hoedspruit)-for the 2006-07, 2007-08, and 2008-09 seasons. Volumetric spore trap systems (20 liter/min capacity) (Interlock Systems, Pretoria, South Africa) with the orifice $0.5 \mathrm{~m}$ above soil level were used for ascospore monitoring. Spore traps were positioned between trees at least 4 to 5 rows into mature citrus orchards ( $>13$ years old) that were mostly surrounded by other citrus orchards. Spores were trapped onto a circular spore trap disc that was divided into octants, which represented 8 days. Each day-section was divided into eight sections (10 by 8 by $8.5 \mathrm{~mm}$ ), representing consecutive 3-h intervals. Prior to placing the disc in the spore trap, it was sprayed with a fine film of petroleum jelly spray (PJS, Interlock Systems). After 7 days in the orchard, the disc was replaced with a clean disc and brought into the laboratory for further processing. Discs were stained with cotton blue in lactic acid (1:600 [wt/vol]) and the total number of Guignardia ascospores counted in six separate microscope fields on a compound microscope at $\times 400$ magnification. Guignardia ascospore identification was based on morphology as described by Sutton and Waterston (35). Ascospores of G. citricarpa and the endophytic Phyllosticta capitalensis (formerly G. mangiferae) could not be distinguished (1,7). Total number of ascospores trapped per 3-h interval was converted to ascospores trapped per cubic meter of air (spores $\left./ \mathrm{m}^{3}\right)$.
Weather stations (Adcon Telemetry Inc., Klosterneuburg, Austria) in close proximity $(<1 \mathrm{~km})$ from the spore traps made hourly recordings of rainfall (in millimeters), mean temperature (in ${ }^{\circ} \mathrm{C}$ ), and percent relative humidity $(\mathrm{RH})$ throughout the spore trapping period and the preceding months.

Effect of rainfall, temperature, RH and time of day on ascospore release. Ascospore events. Hourly weather data were transformed to 3-hourly data as total rainfall and means of temperature and RH, and a Pearson's correlation coefficient was calculated for these variables and 3-hourly spore trap data. For each data set, quantiles were estimated for data recorded during ascospore release events (i.e., a 3-h interval in which Guignardia ascospores were trapped) using the empirical distribution function (with averaging) in XLSTAT (version 2010.2.03; www.xlstat.com). Means and coefficients of variation (standard deviance expressed as percentage of mean [CV\%]) between data sets were calculated. The Portsgate data set for 2006-07 was not considered due to missing weather data during September to November. To determine whether time of day had an effect on ascospore release, analysis of variance and Fisher's test for least significant difference between means at $95 \%$ confidence interval were conducted on the number of ascospore events and spore trap data (spores $/ \mathrm{m}^{3}$ ) per daily 3-h time interval for the different spore trapping months (excluding September and March).

Ascospore days. The data sets with 3-hourly weather and spore trap data were transformed to daily data as daily minimum, average, and maximum temperature $\left(\mathrm{T}_{\min }, \mathrm{T}_{\mathrm{avg}}\right.$, and $\mathrm{T}_{\max }$, respectively) and relative humidity $\left(\mathrm{RH}_{\min }, \mathrm{RH}_{\mathrm{avg}}\right.$, and $\mathrm{RH}_{\max }$, respectively); daily vapor pressure deficit $\left(\mathrm{VPD}=\left(1-\mathrm{RH}_{\mathrm{avg}} / 100\right) \times 6.11 \times\right.$ $\left.\exp \left[\left(17.47 \times \mathrm{T}_{\mathrm{avg}}\right) /\left(239+\mathrm{T}_{\mathrm{avg}}\right)\right]\right)(29)$; and daily rainfall. Additionally, means were also calculated for the 3 and 7 days leading up to a spore event. Daily means were summarized using descriptive statistics (XLSTAT, version 2010.2.03) as described above.

Modeling the effect of rainfall, temperature, and $\mathrm{RH}$ on pseudothecium maturation and ascospore release. Degree-day accumulation was calculated from the daily weather data sets using 1 July (mid-winter) as biofix and $10^{\circ} \mathrm{C}$ as base temperature (13), using the formula $\left[\left(\mathrm{T}_{\max }+\mathrm{T}_{\min }\right) / 2\right]-10^{\circ} \mathrm{C}$ to calculate the daily degree-day contribution (DDtemp) (14). Because complete weather data sets were required for the degree-day calculation, the data sets for Mahela in 2008-09 (missing weather data in winter) and Portsgate in 2006-07 were not considered. In order to address the wet-dry requirement for pseudothecium maturation, degree-day accumulation was calculated for rainy $($ DDrain $=$ DDtemp accumulation only on days with measurable rainfall [>0.1 mm]), humid (DDvpd = DDtemp accumulation only on days with VPD $<5 \mathrm{hPa}$ ), and rainy or humid days (DDwet = DDtemp accumulation only on days with measurable rainfall [ $>0.1 \mathrm{~mm}$ ] or VPD $<5 \mathrm{hPa}$ ) as described by Rossi et al. (29). Additionally, DDwet3d was calculated similarly to DDwet but on days with a 3-day cumulative rainfall of $>0.2 \mathrm{~mm}$.

Pseudothecium maturation and onset of ascospore release. The two prediction models described by Rossi et al. (29) were adapted and evaluated for pseudothecium maturation and subsequent ascospore discharge. First ascospore discharge was modeled using the logistic regression procedure in XLSTAT and a Gompertz model with maximization of Firth's penalized likelihood function using the Newton-Raphson algorithm. Regression was performed with DDtemp, DDrain, DDvpd, DDwet, and DDwet3d data as explanatory variables on rainy or humid days (3-day cumulative rainfall $>0.2 \mathrm{~mm}$ or VPD $<5 \mathrm{hPa}$ ) from 1 July to first meaningful ascospore discharge (arbitrarily chosen as 120 spores $/ \mathrm{m}^{3}$ trapped/ day). The dependent variables were the value 0 when no ascospores were trapped and 1 when ascospores where trapped on that day. Best model selection was based on Schwarz's Bayesian Criterion (33), the coefficient of determination adjusted following Nagelkerke (24) and Youden's index (16). Data from Letaba Oranje (2007-08 and 2008-09), Mahela (2006-07 and 2007-08), 
and Portsgate (2007-08 and 2008-09) were used for model building (136 cases), while one season's data from Letaba Oranje (2006-07) were used for model validation (23 cases). Additionally, the model was also tested on long-term historical weather data obtained for South African, Brazilian, and U.S. locations with known presence or absence of G. citricarpa, as well as European locations that were predicted as marginally suitable for G. citricarpa in recent CLIMEX modeling $(4,5)$ (Table 1). For these locations, DDtemp calculation was based on long-term monthly weather data (mean $\mathrm{T}_{\max }$ and $\mathrm{T}_{\min }$ ).

Ascospore release. To model ascospore release, cumulative ascospore data for each data set were normalized and relative ascospore dose expressed as the proportion of ascospores trapped (PAT) on a 0-to-1 scale (27). By using the nonlinear regression procedure in XLSTAT and a Gompertz function, PAT of each data set was modeled against DDtemp2, DDrain2, DDvpd2, or DDwet 2 data, which were calculated as described for DDtemp, DDrain, DDvpd, and DDwet but using the first seasonal ascospore trap day as biofix. The model was built on the complete data set and best model selected using the coefficient of determination and root-mean-square error (RMSE). To validate, the best model was fitted to each of the seven data sets, compared with a data set-specific model, and evaluated against measured PAT from each data set by linear regression between predicted and measured data points (38). Additionally, daily and 7-day ascospore peaks (daily or 7-day accumulation in PAT) were correlated with predicted ascospore peaks for all data sets.

\section{RESULTS}

Effect of rainfall, temperature, RH, and time of day on ascospore release. Ascospore events. Apart from the Portsgate 2006-07 data, which were not included, the weather and spore trapping data were acceptably complete, with only 30 hourly weather data points missing. From the remaining eight data sets, 2,000 3-hourly ascospore events, in total, were recorded (Table 2). The first ascospores trapped were recorded from 8 September to 18 October and total seasonal numbers of ascospores were 11,242 to 80,445 spores $/ \mathrm{m}^{3}$ trapped during 165 to 321 ascospore events/ season/locality. Analyses of variance of ascospore events and spore density (spores $/ \mathrm{m}^{3}$ ) data per 3-h daily time interval (October to February only) did not indicate any significant monthinterval interaction $(P=0.993$ and 0.890 , respectively) but found significant effects for daily time interval $(P=0.059$ and 0.167 , respectively) and month $(P<0.0001$ and $P=0.001$, respectively). Number of ascospore events per daily time interval was poorly correlated with the ascospore density $(r=0.371)$. Significantly more ascospore events and higher spore densities were recorded during November to January (50.4 to 56.5 events yielding 6,183 to 8,215 spores $/ \mathrm{m}^{3}$ ) than those in October and February (42.5 and 29.7 events yielding 2,247 and 2,705 spores $/ \mathrm{m}^{3}$, respectively). Ascospores were trapped throughout the day and night, with average annual events per interval of 23.6 to 35.0. More events were recorded from 1200 to $2400 \mathrm{~h}$ (30.4 to 35.0 events) than from 0000 to $0600 \mathrm{~h}$ (23.6 to 29.1 events). Average ascospore

TABLE 1. Citrus-producing locations for which long-term monthly average weather data for daily temperature (minimum, average and maximum) were sourced

\begin{tabular}{|c|c|c|c|c|c|}
\hline \multirow[b]{2}{*}{ Location } & \multirow[b]{2}{*}{$\mathrm{CBS}^{\mathrm{a}}$} & \multicolumn{4}{|c|}{ Weather station information } \\
\hline & & Coordinates & Altitude (m) & Years & Source ${ }^{b}$ \\
\hline \multicolumn{6}{|l|}{ South Africa } \\
\hline Nelspruit (Mpumalanga) & Moderate & $25.45^{\circ} \mathrm{S} 30.97^{\circ} \mathrm{E}$ & 660 & 65 & ARC Agromet \\
\hline Letsitele (Limpopo) & Moderate & $23.87^{\circ} \mathrm{S} 30.32^{\circ} \mathrm{E}$ & 623 & 34 & ARC Agromet \\
\hline Kirkwood (E-Cape) & Low & $33.40^{\circ} \mathrm{S} 25.35^{\circ} \mathrm{E}$ & 96 & 16 & ARC Agromet \\
\hline Addo (E-Cape) & Low & $33.57^{\circ} \mathrm{S} 25.70^{\circ} \mathrm{E}$ & 85 & 21 & ARC Agromet \\
\hline Patensie (E-Cape) & Low & $33.77^{\circ} \mathrm{S} 24.82^{\circ} \mathrm{E}$ & 93 & 29 & ARC Agromet \\
\hline Citrusdal (W-Cape) & Absent & $32.57^{\circ} \mathrm{S} 18.98^{\circ} \mathrm{E}$ & 198 & 30 & ARC Agromet \\
\hline Stellenbosch (W-Cape) & Absent & $33.90^{\circ} \mathrm{S} 18.87^{\circ} \mathrm{E}$ & 146 & 36 & ARC Agromet \\
\hline \multicolumn{6}{|l|}{ United States } \\
\hline Lake Alfred, Florida & Absent & $28.10^{\circ} \mathrm{N} 81.71^{\circ} \mathrm{W}$ & 42 & 30 & www.worldclimate.com \\
\hline Fort Pierce, Florida & Absent & $27.46^{\circ} \mathrm{N} 80.35^{\circ} \mathrm{W}$ & 7 & 30 & www.worldclimate.com \\
\hline Riverside, California & Absent & $33.96^{\circ} \mathrm{N} 117.35^{\circ} \mathrm{W}$ & 300 & 30 & www.worldclimate.com \\
\hline \multicolumn{6}{|l|}{ Brazil } \\
\hline Campinas, Sao Paulo & High & $22.48^{\circ} \mathrm{S} 47.03^{\circ} \mathrm{W}$ & 640 & 30 & http://orion.cpa.unicamp.br \\
\hline \multicolumn{6}{|l|}{ Italy } \\
\hline Messina & Absent & $38.20^{\circ} \mathrm{N} 15.50^{\circ} \mathrm{E}$ & 59 & 30 & www.worldclimate.com \\
\hline Pontecagnano & Absent & $40.60^{\circ} \mathrm{N} 14.90^{\circ} \mathrm{E}$ & 30 & 27 & www.worldclimate.com \\
\hline \multicolumn{6}{|l|}{ Spain } \\
\hline Valencia & Absent & $39.50^{\circ} \mathrm{N} 0.46^{\circ} \mathrm{W}$ & 62 & 30 & www.euroweather.net \\
\hline
\end{tabular}

a Citrus black spot (CBS) prevalence.

b ARC Agromet = ARC Institute for Soil, Climate and Water, Agromet, Stellenbosch, South Africa.

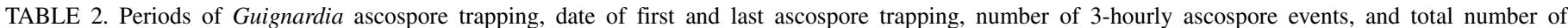
ascospores trapped at three localities during three seasons

\begin{tabular}{|c|c|c|c|c|c|}
\hline \multirow[b]{2}{*}{ Data set, season } & \multirow[b]{2}{*}{ Trapping period } & \multicolumn{3}{|c|}{ Ascospore events } & \multirow[b]{2}{*}{ Total spores $/ \mathrm{m}^{3}$} \\
\hline & & First & Last & Number & \\
\hline \multicolumn{6}{|l|}{ Letaba Oranje } \\
\hline $2006-07$ & 2 October 2006-19 February 2007 & 18 October & 18 February & 204 & 11,242 \\
\hline $2007-08$ & 17 September 2007-28 March 2008 & 21 September & 27 March & 260 & 14,029 \\
\hline $2008-09$ & 22 September 2008-23 February 2009 & 26 September & 21 February & 165 & 26,952 \\
\hline \multicolumn{6}{|l|}{ Mahela } \\
\hline $2006-07$ & 30 Aug 2006-2 April 2007 & 8 September & 31 March & 280 & 14,341 \\
\hline $2007-08$ & 17 September 2007-31 March 2008 & 26 September & 27 March & 321 & 25,175 \\
\hline $2008-09$ & 29 September 2008-23 February 2009 & 1 October & 22 February & 276 & 30,940 \\
\hline \multicolumn{6}{|l|}{ Portsgate } \\
\hline $2007-08$ & 20 September 2007-17 March 2008 & 29 September & 13 March & 227 & 16,743 \\
\hline $2008-09$ & 22 September 2008-23 February 2009 & 22 September & 23 February & 267 & 80,445 \\
\hline
\end{tabular}


density varied from 1,700 to 5,489 spores $/ \mathrm{m}^{3}$, with the highest densities recorded from 1200 to $2100 \mathrm{~h}(3,465$ to 5,489 spores $/ \mathrm{m}^{3}$ ).

Quantile estimation of spore trap data indicated that relatively low numbers of ascospores were trapped during the majority of 3hourly spore events (24 to 48 spores $/ \mathrm{m}^{3}$ ) (Table 3 ). Larger numbers of spores were trapped in 10,5, and $1 \%$ of events: 234.2 , 475.9, and 1,333.2 spores $/ \mathrm{m}^{3}$, respectively. Large variation was also observed between localities and seasons. Ascospore trap data were poorly correlated with $\mathrm{RH}(r=0.04 ; P=0.071)$, temperature $(r=0.05 ; P=0.039)$, and VPD $(r=-0.01 ; P=0.536)$. Correlation with rainfall was slightly better $(r=0.21 ; P<0.0001)$.

Mean $\mathrm{T}_{\min }$ at which ascospores were trapped was $13.4^{\circ} \mathrm{C}$ but the mean first and fifth percentiles were 15.9 and $17.8^{\circ} \mathrm{C}$, respectively (Table 3 ). This clearly indicates that the vast majority $(>95 \%)$ of ascospore release events occurred at temperatures $>\approx 18^{\circ} \mathrm{C}$. The mean maximum temperature at which ascospores were trapped was $37.2^{\circ} \mathrm{C}$ but the 75 th percentile was $\approx 10^{\circ} \mathrm{C}$ lower, at $27.6^{\circ} \mathrm{C}$, and the 95 th percentile was at $33^{\circ} \mathrm{C}$. The median temperature at which ascospores were released was $23.6^{\circ} \mathrm{C}$. In general, very little variation was observed between temperature quantiles of the different data sets; CV\% values for means of the 5th to 95 th percentile were 7.1 to $3.9 \%$.

Ascospores were trapped at relative humidity as low as $22.4 \%$ but most were trapped at higher humidity: 5th, 25th and 50th percentile at 38.8, 59.3, and 76.4\%, respectively (Table 3). The median VPD for ascospore events was $6.9 \mathrm{hPa}$. As for temperature means, little variation was observed between RH means $(<16.5 \%)$, but larger variation was observed between VPD means, especially in the first and second quartiles (141.1 to $10.1 \%$ ).

Surprisingly, rainfall was infrequently measured during the 3-hourly spore events (Table 3). For the eight data sets, rainfall was only recorded during $15.7 \%$ of the 2,000 spore events: the 90th percentile was $1.5 \mathrm{~mm}$, 95th percentile was $5 \mathrm{~mm}$, and 99th percentile was $20.3 \mathrm{~mm}$.

Ascospore days. Weather data were analyzed from 635 days on which Guignardia ascospore were trapped. Because one or more ascospore events occurred on ascospore days, the number of spores trapped per day was higher (Table 4) than those reported for 3-hourly spore events (Table 3). Standard deviation from the mean was very high in the third quantile (CV\% > 60.7\%), indicating large differences in the number of spores trapped between seasons and localities. As was observed for data from the 3-hourly ascospore events, daily data were also poorly correlated with the weather variables $(r<0.15)$.

Descriptive statistics of the daily temperature data measured during ascospore days (Table 4) showed lower 5th and 25th percentile values for daily $\mathrm{T}_{\min }\left(15.1\right.$ and $18.1^{\circ} \mathrm{C}$, respectively) than were observed for the 3-hourly intervals $\left(17.8\right.$ and $21.0^{\circ} \mathrm{C}$, respectively) (Table 3 ). Likewise, mean daily $\mathrm{T}_{\min }\left(11.4^{\circ} \mathrm{C}\right)$ was lower than the respective mean observed for 3-hourly intervals $\left(13.4^{\circ} \mathrm{C}\right)$. The 5 th and 25 th percentile values for daily $\mathrm{T}_{\text {avg }}$ were 19.0 and $22.6^{\circ} \mathrm{C}$, respectively. Quantiles estimated for temperature data varied little between seasons and localities, with CV\% values mostly $<10 \%$.

Median RH values recorded on ascospore days were 48.7, 72.1, and $92.8 \%$ for $\mathrm{RH}_{\text {min }}, \mathrm{RH}_{\text {avg }}$, and $\mathrm{RH}_{\max }$, respectively (Table 4). Median $\mathrm{RH}_{\text {avg }}$ was comparable with $\mathrm{RH}$ recorded during ascospore events $(76.4 \%)$. Daily VPD values were higher than those calculated for ascospore events, with the median at $8.7 \mathrm{hPa}$.

Rainfall was recorded on 243 of the 635 ascospore days. The 50th and 75th percentiles for daily rainfall were 0 and $2.4 \mathrm{~mm}$, respectively (Table 4). When rainfall during the 3 days leading up to an ascospore event was considered, these values were 2.1 and $13 \mathrm{~mm}$, respectively; 396 days conformed to this criterion. In $81.6 \%$ of the cases (518 days), rainfall was recorded in the 7 days leading up to the event.

Modeling the effect of rainfall, temperature, and $\mathrm{RH}$ on pseudothecium maturation and ascospore release. Pseudothecium maturation and onset of ascospore release. Mean DDtemp accumulation (results not shown) until the first and fifth percentile of ascospore events was 768.3 and $907.1^{\circ} \mathrm{C}$, respectively. The 25 th percentile and median values were $1,324.9$ and $1,839.6^{\circ} \mathrm{C}$, respectively. $\mathrm{CV} \%$ values for these values were remarkably low $(<17 \%)$. In contrast, CV\% for the 1 st to 25 th percentiles estimated for DDrain, DDvpd, DDwet, and DDwet3d were markedly higher (33 to $77 \%$ ).

Two models for prediction of the onset of ascospore dispersal were selected based on the criteria used (Table 5). The temperature model (T-model) using DDtemp as sole variable had an $R^{2}$

TABLE 3. Means and coefficients of variation (\%) of quantiles estimated for 3-hourly temperature (Temp), relative humidity (RH), vapor pressure deficit VPD; $(\mathrm{hPa})$, rainfall $(\mathrm{mm})$, and ascospore trapping $\left(\right.$ Spores $\left./ \mathrm{m}^{3}\right)$ data measured during 2,000 Guignardia ascospore release events at three localities over three seasons ${ }^{\mathrm{a}}$

\begin{tabular}{|c|c|c|c|c|c|c|c|c|c|}
\hline Variable & Min & $1 \%$ & $5 \%$ & $10 \%$ & $25 \%$ & $50 \%$ & $75 \%$ & $95 \%$ & Max \\
\hline $\operatorname{Temp}\left({ }^{\circ} \mathrm{C}\right)$ & $13.4(14.5)$ & $15.9(11.1)$ & $17.8(7.1)$ & $18.9(6.4)$ & $21.0(6.1)$ & $23.6(5.4)$ & $27.6(5.8)$ & $33.0(3.9)$ & $37.2(3.8)$ \\
\hline RH (\%) & $22.4(13.1)$ & $26.6(16.5)$ & 38.8 (14.2) & $46.5(13.8)$ & $59.3(13.8)$ & $76.4(9.1)$ & $88.8(6.4)$ & $97.2(3.4)$ & $98.0(2.9)$ \\
\hline VPD & $0.4(141.3)$ & $0.4(141.1)$ & $0.6(131.9)$ & $1.0(91.2)$ & $2.8(49.7)$ & $6.9(33.8)$ & $14.9(30.1)$ & $30.8(10.1)$ & $48.3(8.3)$ \\
\hline Rain (mm) & $0.0(0.0)$ & $0.0(0.0)$ & $0.0(0.0)$ & $0.0(0.0)$ & $0.0(0.0)$ & $0.0(0.0)$ & $0.0(0.0)$ & $5.0(58.9)$ & $43.1(33.3)$ \\
\hline Spores $/ \mathrm{m}^{3}$ & $24.0(0.0)$ & $24.0(0.0)$ & $24.0(0.0)$ & $24.0(0.0)$ & $27.0(31.4)$ & $39.0(31.8)$ & $81.1(49.9)$ & $475.9(118.4)$ & $1,909.7(98.2)$ \\
\hline
\end{tabular}

ain = minimum and Max = maximum.

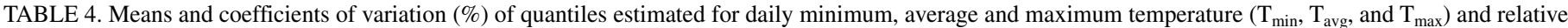

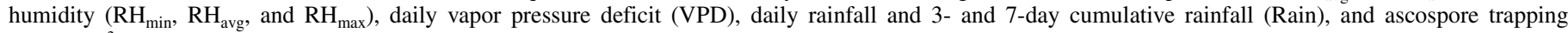
$\left(\right.$ Spores $\left./ \mathrm{m}^{3}\right)$ data measured during 635 days on which Guignardia ascospores were trapped at three localities over three seasons ${ }^{\mathrm{a}}$

\begin{tabular}{|c|c|c|c|c|c|c|c|c|c|}
\hline Variable & Min & $1 \%$ & $5 \%$ & $10 \%$ & $25 \%$ & $50 \%$ & $75 \%$ & $95 \%$ & Max \\
\hline $\mathrm{T}_{\min }\left({ }^{\circ} \mathrm{C}\right)$ & $11.4(17.6)$ & $13.6(8.9)$ & $15.1(5.4)$ & $16.5(5.6)$ & $18.1(5.7)$ & $19.9(5.1)$ & $21.4(3.6)$ & $23.1(2.0)$ & $24.6(5.1)$ \\
\hline $\mathrm{T}_{\mathrm{avg}}\left({ }^{\circ} \mathrm{C}\right)$ & $16.5(6.8)$ & $17.7(5.9)$ & $19.0(5.7)$ & $20.0(6.8)$ & $22.6(5.3)$ & $24.5(4.0)$ & $26.0(3.2)$ & $27.9(3.6)$ & $29.3(2.7)$ \\
\hline $\mathrm{T}_{\max }\left({ }^{\circ} \mathrm{C}\right)$ & $18.2(9.1)$ & $19.7(10.6)$ & $21.5(8.0)$ & $23.4(7.7)$ & $27.0(6.6)$ & $29.9(4.7)$ & $32.5(3.7)$ & $35.5(3.6)$ & $37.6(3.5)$ \\
\hline $\mathrm{RH}_{\min }(\%)$ & $17.7(25.3)$ & $22.2(18.5)$ & $26.3(14.6)$ & $31.7(10.0)$ & $39.3(9.3)$ & $48.7(12.2)$ & $60.0(10.6)$ & $80.9(6.1)$ & $93.2(4.7)$ \\
\hline $\mathrm{RH}_{\mathrm{avg}}(\%)$ & $44.9(15.5)$ & $50.5(11.0)$ & $55.1(7.2)$ & $59.2(6.7)$ & $65.2(6.0)$ & $72.1(6.6)$ & $78.6(6.0)$ & $91.2(4.1)$ & $96.1(3.6)$ \\
\hline $\mathrm{RH}_{\max }(\%)$ & $65.1(14.2)$ & $73.1(8.7)$ & $78.0(6.6)$ & $81.5(5.6)$ & $86.9(4.6)$ & $92.8(3.7)$ & $96.5(3.7)$ & $97.6(3.2)$ & $97.8(3.0)$ \\
\hline VPD (hPa) & $0.9(95.2)$ & $1.4(63.1)$ & $2.2(44.5)$ & $3.5(40.6)$ & $6.0(26.4)$ & $8.7(20.3)$ & $11.4(13.8)$ & $15.4(13.0)$ & $20.4(12.9)$ \\
\hline Rain (mm) & $0.0(0.0)$ & $0.0(0.0)$ & $0.0(0.0)$ & $0.0(0.0)$ & $0.0(0.0)$ & $0.0(0.0)$ & $2.4(69.4)$ & 34.7 (30.9) & $104.1(28.1)$ \\
\hline Rain (3-day) (mm) & $0.0(0.0)$ & $0.0(0.0)$ & $0.0(0.0)$ & $0.0(0.0)$ & $0.0(0.0)$ & $2.1(93.1)$ & $13.0(23.4)$ & $71.7(26.1)$ & 154.4 (22.7) \\
\hline Rain (7-day) (mm) & $0.0(0.0)$ & $0.0(0.0)$ & $0.0(0.0)$ & $0.0(0.0)$ & $1.8(147.7)$ & $10.1(33.2)$ & $35.0(15.6)$ & $116.8(30.6)$ & $197.8(23.6)$ \\
\hline Spores $/ \mathrm{m}^{3}$ & $24.0(0.0)$ & $24.0(0.0)$ & $24.0(0.0)$ & $37.7(34.0)$ & $48.0(0.0)$ & 114.7 (33.9) & $278.0(60.7)$ & $1,410.4(112.2)$ & $3,201.8(121.3)$ \\
\hline
\end{tabular}

${ }^{\mathrm{a}}$ Min = minimum, Avg = average, and Max = maximum. 
value following Nagelkerke of 0.608 , and was preferred based on Schwarz's Bayesian Criterion (112.62), whereas the temperature/ moisture model (T/M-model) had a marginally better $R^{2}$ value of 0.658 . Youden's index for the T-model was slightly better $(0.643$ versus 0.587 ) but, in validation, the T/M-model showed slightly superior specificity (100 versus $80 \%$ ).

The T-model predicted a 0.5 probability at $767.9^{\circ} \mathrm{C}$ DDtemp, which corresponded to the 1 st percentile for DDtemp data $\left(768.3^{\circ} \mathrm{C}\right)$ (Table 3), whereas predicted DDtemp values for 0.7 $\left(933.0^{\circ} \mathrm{C}\right), 0.8\left(1,049.5^{\circ} \mathrm{C}\right), 0.9\left(1,235.9^{\circ} \mathrm{C}\right)$, and $0.99\left(1,819.6^{\circ} \mathrm{C}\right)$ probabilities corresponded to the 5 th percentile $\left(907.1^{\circ} \mathrm{C}\right), 10$ th $\left(1,068.9^{\circ} \mathrm{C}\right), 25$ th $\left(1,324.9^{\circ} \mathrm{C}\right)$, and 50 th $\left(1,839.6^{\circ} \mathrm{C}\right)$ percentiles, respectively. Predictions using a probability of 0.5 differed, on average, 2 days, ranging from -16 to 21 days, from the first seasonal ascospore capture (Table 6). Measured PAT values at these predicted dates were an average of $0.004(0-0.010)$. A probability of 0.7 predicted first discharge 15 days after actual trapping event (average PAT of 0.054 ), while 0.8 was 25 days after the actual trapping event (average PAT of 0.095).

DDtemp was the primary component in the T/M-model (Wald's $\chi^{2} 17.035$, compared with 1.539 and 0.678 for DDvpd and DDrain, respectively) and this model yielded predictions similar to those of the T-model. Predicted dates for first discharge differed from the actual release by 6,19 , and 29 days for the 0.5 , 0.7 , and 0.8 probabilities, respectively. Predictions were, on average, 4 days later than the T-model, although this was not consistent between data sets; for instance, predictions with the T/Mmodel were earlier at Mahela 2007-08 and Portsgate 2008-09. For Letaba Oranje 2007-08, the models differed substantially, with the T/M-model predicting first discharge 21, 19, and 26 days later than the $\mathrm{T}$ model (probabilities of $0.5,0.7$, and 0.8 , respectively). From 27 September to 10 October 2007, the increase in DDtemp $\left(739.0\right.$ to $\left.885.2^{\circ} \mathrm{C}\right)$ was consistent with that observed in the preceding days but a sharp increase in DDvpd $\left(27.3\right.$ to $\left.70.9^{\circ} \mathrm{C}\right)$ and DDrain $\left(4.2\right.$ to $\left.150.3^{\circ} \mathrm{C}\right)$ was observed. This resulted in the predicted T/M probabilities declining from 0.435 on 29 September to 0.286 on 9 October, whereafter it increased again but at rates similar to those observed prior to this period; hence, the 3-week "delayed" prediction. Further perusal of T/Mmodel behavior in other data sets showed that predicted probability decreased following an increase in DDrain, regardless of an increase in DDvpd; this decrease was most pronounced in regions around the inflection points of the Gompertz curve (results not shown).

TABLE 5. Goodness-of-fit statistics, performance, and validation of two Gompertz models describing the effect of physiological time on Guignardia pseudothecium maturation and the probability of onset of seasonal ascospore release

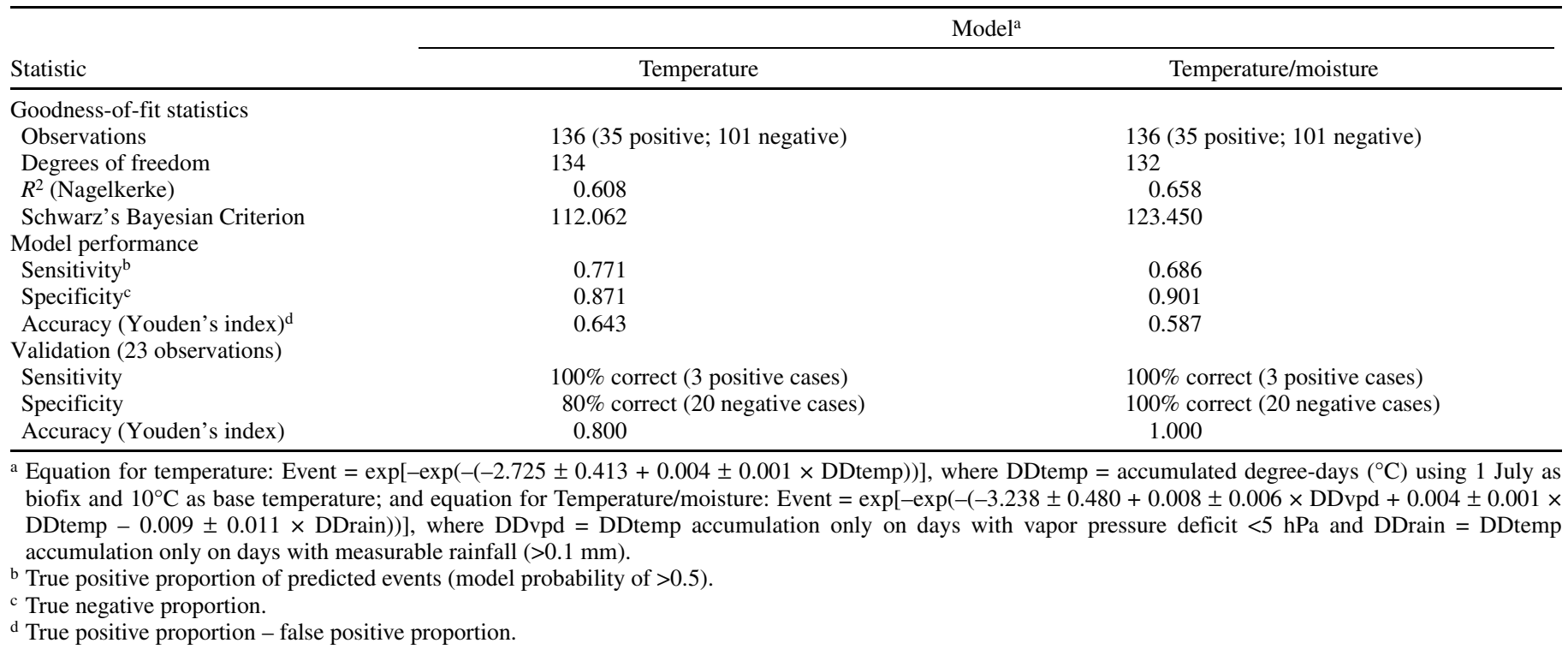

TABLE 6. Comparison of actual and predicted dates for first seasonal Guignardia ascospore discharge as predicted by the temperature and temperature/moisture models from measured weather data for three localities during three seasons

\begin{tabular}{|c|c|c|c|c|c|c|c|}
\hline \multirow[b]{3}{*}{ Data set, season } & \multirow[b]{3}{*}{ Actual } & \multicolumn{6}{|c|}{ Predicted first seasonal ascospore discharge (days differing from actual; measured PAT) ${ }^{\mathrm{a}}$} \\
\hline & & \multicolumn{3}{|c|}{ Temperature model ${ }^{\mathrm{b}}$} & \multicolumn{3}{|c|}{ Temperature/moisture model ${ }^{\mathrm{c}}$} \\
\hline & & 0.5 & 0.7 & 0.8 & 0.5 & 0.7 & 0.8 \\
\hline $2006-07$ & 18 October & $-16 ; 0.000$ & $-2 ; 0.000$ & $6 ; 0.017$ & $-7 ; 0.000$ & $5 ; 0.017$ & $14 ; 0.026$ \\
\hline 2007-08 & 21 September & $9 ; 0.009$ & $23 ; 0.212$ & $33 ; 0.288$ & $30 ; 0.265$ & $42 ; 0.370$ & $59 ; 0.425$ \\
\hline 2008-09 & 26 September & $0 ; 0.001$ & $14 ; 0.005$ & $23 ; 0.007$ & $4 ; 0.004$ & $16 ; 0.005$ & $26 ; 0.015$ \\
\hline \multicolumn{8}{|l|}{ Mahela } \\
\hline \multicolumn{8}{|l|}{ Portsgate } \\
\hline 2007-08 & 29 September & $-6 ; 0.000$ & $9 ; 0.070$ & $19 ; 0.151$ & $1 ; 0.001$ & $17 ; 0.111$ & $25 ; 0.202$ \\
\hline 2008-09 & 22 September & $1 ; 0.001$ & $14 ; 0.006$ & $23 ; 0.007$ & $-5 ; 0.000$ & $8 ; 0.004$ & $16 ; 0.006$ \\
\hline Average & $\ldots$ & $2 ; 0.004$ & $15 ; 0.054$ & $25 ; 0.095$ & $6 ; 0.040$ & $19 ; 0.082$ & $29 ; 0.119$ \\
\hline
\end{tabular}

a Probability of 0.5, 0.7, and 0.8; PAT = proportion of Guignardia ascospores trapped.

${ }^{\mathrm{b}}$ Event (probability) $=\exp \left[-\exp (-(-2.725+0.004 \times\right.$ DDtemp) $)]$, where DDtemp $=$ accumulated degree-days $\left({ }^{\circ} \mathrm{C}\right)$ using 1 July as biofix and $10^{\circ} \mathrm{C}$ as base temperature.

${ }^{\mathrm{c}}$ Event (probability) $=\exp [-\exp (-(-3.238+0.008 \times$ DDvpd +0.004 DDtemp $-0.009 \times$ DDrain) $)]$, where DDvpd $=$ DDtemp accumulation only on days with vapor pressure deficit $<5 \mathrm{hPa}$ and DDrain $=$ DDtemp accumulation only on days with measurable rainfall $(>0.1 \mathrm{~mm})$. 
The T-model was used to predict onset of ascospore release (using 0.5 to 0.7 probabilities, which equaled first to fifth percentile of ascospore release in our data sets) in different climates using long-term weather data. For the South African sites, the model predicted onset of ascospore release in the warm Letsitele climate (Limpopo province) from beginning to mid-October and $\approx 1$ week later for the slightly cooler Nelspruit area (Mpumalanga province) (Fig. 1). For the Eastern Cape province localities (Kirkwood, Addo, and Patensie), onset of ascospore release was predicted for the second to third week in November, whereas onset of ascospore release for the CBS-absent localities, Citrusdal (mid- to end of November) and Stellenbosch (end of November to beginning of December), was predicted 1 to 3 weeks later. For Campinas in Brazil, onset of ascospore release was predicted for mid- to end of September; for Fort Pierce in Florida, similar to Letsitele (beginning to mid-April; northern hemisphere) and Lake Alfred (Florida) $\approx 1$ week later than Nelspruit (mid- to end April; northern hemisphere). Prediction of the onset of ascospore release for Mediterranean-type climates where CBS does not occur was markedly later than predictions for the CBS-absent localities in South Africa (Stellenbosch and Citrusdal): mid-June for Valencia (Spain), Messina (Italy), and Riverside (California) and $\approx 5$ weeks later (mid- to end of July) for the cooler Pontecagnano (Italy).

Ascospore release. Seasonal ascospore release (PAT) was poorly predicted from DDrain2 $\left(R^{2}=0.143\right.$; RMSE $\left.=0.554\right)$ and DDvpd2 $\left(R^{2}=0.144 ;\right.$ RMSE $\left.=0.553\right)$ data, whereas DDtemp2 $\left(R^{2}=0.865 ; \mathrm{RMSE}=0.129\right)$ and DDwet $2\left(R^{2}=0.908 ; \mathrm{RMSE}=\right.$ $0.107)$ yielded very good fits using the Gompertz equation; the model using DDwet2 as response variable was selected as best model: PAT $=\exp (-4.096 \times \exp (-0.005 \times$ DDwet 2$)$. PAT predicted by this generic PAT model (built on complete data set) as well as site-specific PAT models (built on data sets for each site and season) were compared with measured PAT for each data set (Table 7). The site-specific models fitted very well with actual data $\left(R^{2}\right.$ values $>0.952 ;$ RMSE $\left.<0.077\right)$. Linear regression between PAT predicted by the generic model and measured PAT generally showed similar degrees of accuracy $\left(R^{2}\right.$ values $\left.>0.976\right)$, although the generic model fitted less accurately to measured PAT at Mahela 2006-07 $\left(R^{2}=0.926\right)$ and Portsgate 2008-09 $\left(R^{2}=\right.$ 0.893).

Measured seasonal ascospore data, PAT predicted by the generic and site-specific models, daily rainfall, and predicted onset of ascospore release for the various sites and seasons are shown in Figures 2 to 4 . Lag phases following onset of ascospore release until PAT started to increase $(>\approx 0.1)$ ranged from 4- to 10 -week periods (Figs. 2A and C, 3A, and $4 \mathrm{~B}$ ) to brief 1- to 2-week periods (Figs. 2B, 3B, and 4A). Remarkably, these lag phases were accurately predicted by the DDwet 2 models; most accurately with the site-specific models. For Mahela 2006-07 (Fig. 3A) and Portsgate 2008-09 (Fig. 4B), the lag phases were underestimated by 2 to 3 weeks, whereas both models predicted a longer lag phase than measured for Portsgate 2007-08 (Fig. 4A).

The dates for pseudothecium maturation and onset of ascospore release, predicted by the T- and T/M-models using probabilities of $0.5,0.7$, or 0.8 , commonly occurred during the lag phases observed for seasonal ascospore release patterns. In cases with long lag phases (Figs. 2A and C, 3A, and 4B), probabilities of 0.8 were adequate to predict onset of $>97 \%$ of seasonal ascospore release.
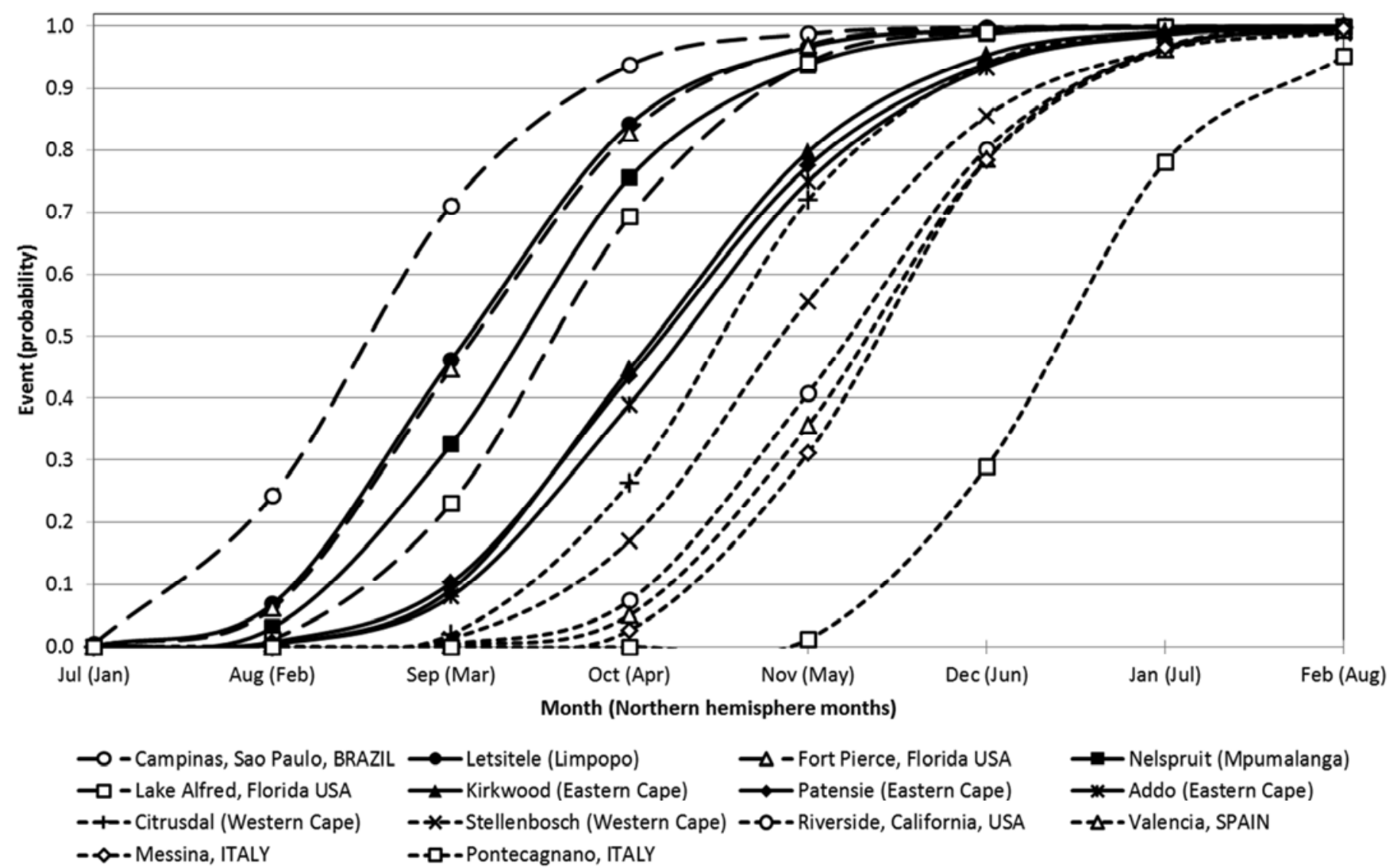

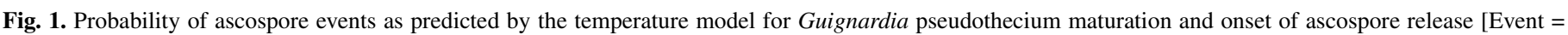

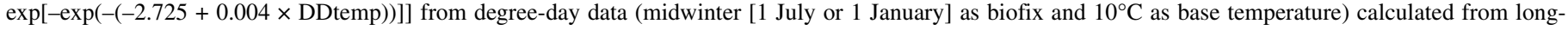

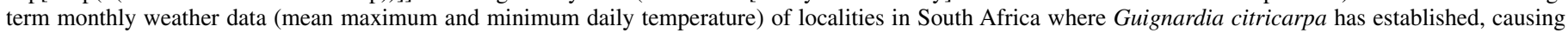

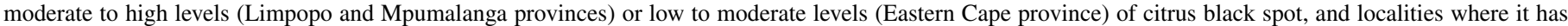

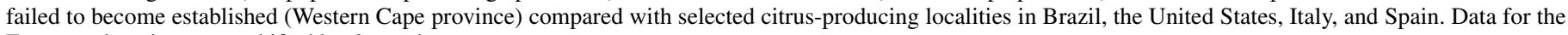
European locations were shifted by 6 months. 
However, in cases with short lag phases (Figs. 2B, 3B, and 4A), the higher probabilities predicted onset of ascospore release when actual release often exceeded 0.1 to 0.2 PAT. In these cases, a probability of 0.5 was more accurate, except for the T/M-model (probability of 0.5 ) for Letaba Oranje 2007-08, where onset was predicted 30 days after actual and at a measured PAT of 0.265 (Table 6; Fig. 2B); factors influencing this delayed prediction were mentioned above.

Following the onset of ascospore release, spore events were recorded on 46 to $64 \%$ of successive days in the spore-trapping periods. Periods when no ascospores were trapped were mostly short ( 1 to 3 days), and longer ascospore-free periods ( $>5$ days) were rare, occurring, on average, 2.6 ( 1 to 5 times) times per season. These periods often occurred during long lag phases but also throughout the season, and could not be explained by time of season or the presence or absence of rainfall (Figs. 2 to 4). The longest ascospore-free period of 31 days was recorded at Mahela during 2007-08 (Fig. 3B), while others in excess of 10 days were also recorded (Figs. 2C, 3A, and 4A).

Ascospore release patterns were generally accurately predicted by the generic model. Exceptions were for Letaba Oranje 200607 and 2008-09 (Fig. 2A and C), where the first 30 to $40 \%$ of ascospores released was accurately predicted but, as the seasons progressed, the model underpredicted the quantity of ascospores released. At Portsgate 2007-08 (Fig. 4A), >25\% of seasonal ascospores were trapped during the 5 weeks following the onset of ascospore release. Both the generic and site-specific models underpredicted this period of ascospore release, especially during the middle 3-week period; most probably due to the lack of rainfall.

The generic ascospore release model generally predicted peaks in ascospore release with reasonable accuracy, although certain notable peaks were not predicted: 28 January to 4 February 2006 (Fig. 2A), 10 October to 4 November 2007, 6 to 8 January 2008 (Fig. 2B), 7 to 12 December 2008, 9 to 10 January 2009 (Fig. 2C), 31 December 2007 to 4 January 2008 (Fig. 3B), 9 to 31 October 2007, 28 January to 1 February 2008 (Fig. 4A), 25 November to 4 December 2008, and 5 to 10 January 2009 (Fig. 4B). Evidence of overprediction was not that apparent and most notably included the underestimation of lag phases mentioned previously (Figs. 3A and 4B) or overprediction of the quantity contribution to PAT: 1 to 23 November 2006 (Fig. 3A) and 21 October to 24 November 2008 (Fig. 4B).

Pearson's correlation coefficients of actual daily and 7-day ascospore peaks and those predicted by site-specific models indicated poor prediction of daily peaks $(0.143$ to 0.407$)$ and fair prediction of 7 -day peaks ( 0.384 to 0.765 ) (Table 7$)$. Likewise, the generic model proved to be inaccurate in predicting daily peaks $(0.141$ to 0.329$)$ and slightly poorer at predicting 7-day peaks $(0.316$ to 0.701$)$ than the site-specific models. Inaccuracy of the 7-day peak prediction was mostly ascribed to prediction of the quantity of ascospores rather than the incidence of ascospore release (results not shown).

\section{DISCUSSION}

This article is the first to describe epidemiological models for Guignardia pseudothecium maturation and ascospore release. The models are based on a comprehensive data set obtained from three localities over three seasons comprising 2,000 ascospore events on 635 days. The goodness-of-fit statistics of these Guignardia models were similar and, in some cases, superior to similar models developed for V. pirina (29). Our models, however, cannot be regarded as specific for G. citricarpa because ascospores of the CBS pathogen could not be distinguished from those of the endophytic $P$. capitalensis $(1,7)$ on spore trap discs. In fact, most literature on CBS and Guignardia spp. in citrus was published prior to the fairly recent identification of this endophytic Phyllosticta sp. in citrus and should be considered with some scrutiny.

McOnie (18) predominantly isolated G. citricarpa over a "Guignardia sp." (i.e., P. capitalensis) from asymptomatic citrus fruit in South African citrus orchards $(\approx 70 \%)$, and also observed a low recovery percentage of $P$. capitalensis from citrus leaves ( 0 to $8.7 \%$ ) and fruit (0 to $0.7 \%$ ) in areas where G. citricarpa was not present (17). In contrast, isolations from asymptomatic fruit obtained from tropical citrus-growing regions (Brazil, Jamaica, Trinidad, and Honduras) yielded markedly higher levels (9.7 to $66.8 \%)$ of $P$. capitalensis. Relatively higher isolation frequencies of $P$. capitalensis were also reported from South America $(2,3,8)$.

Wilting and subsequent wetting and drying requirements of fallen leaves at moderate temperatures $\left(21\right.$ to $\left.28^{\circ} \mathrm{C}\right)$ are accepted requirements for pseudothecium maturation of G. citricarpa, while long wet or dry periods were detrimental $(10,13)$. Kotzé (11) and McOnie (19) observed several rainy days prior to first ascospore discharge. Similarly, Lee and Huang (13) reported moderate levels of precipitation and an even dispersion of rainy days at 21 to $28^{\circ} \mathrm{C}$ as most favorable for pseudothecium maturation. In four cases from our study, ascospores were trapped while no preceding rainfall was measured. Therefore, one needs to consider alternate sources of wetting such as irrigation or heavy dews (10) to be sufficient in allowing maturation of some pseudothecia. The orchards in the present study were irrigated but accurate data regarding frequency and amounts could unfortunately not be obtained. We did, however, observe an average of 8.1 (4 to 10) rainy days from 1 September until onset of $95 \%$ of

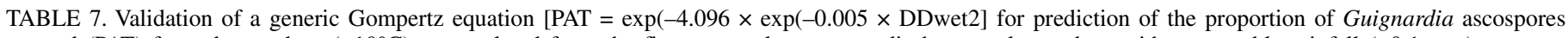

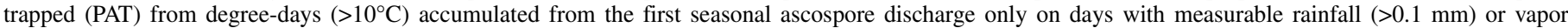

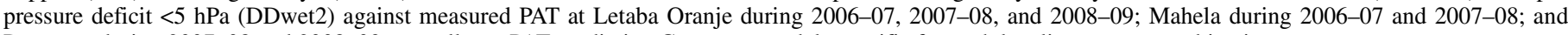
Portsgate during 2007-08 and 2008-09, as well as a PAT-predicting Gompertz models specific for each locality-season combination ${ }^{\mathrm{a}}$

\begin{tabular}{|c|c|c|c|c|c|c|c|c|}
\hline \multirow[b]{4}{*}{ Data set, season } & \multicolumn{8}{|c|}{$\mathrm{PAT}=\exp [\mathrm{A} \times \exp (\mathrm{B} \times \mathrm{DDwet} 2)]$} \\
\hline & \multicolumn{5}{|c|}{ Site-specific models } & \multirow{2}{*}{\multicolumn{3}{|c|}{$\begin{array}{r}\text { Generic model }(\mathrm{A}=-4.096 ; \mathrm{B}=-0.005) \\
\text { Peak prediction }\end{array}$}} \\
\hline & \multirow[b]{2}{*}{ A } & \multirow[b]{2}{*}{ B } & \multirow[b]{2}{*}{$R^{2}(\mathrm{RMSE})$} & \multicolumn{2}{|c|}{ Peak prediction } & & & \\
\hline & & & & Daily & 7-day & $R^{2}$ & Daily & 7-day \\
\hline \multicolumn{9}{|l|}{ Letaba Oranje } \\
\hline $2006-07$ & -5.206 & -0.007 & $0.979(0.051)$ & 0.370 & 0.765 & 0.979 & 0.328 & 0.701 \\
\hline 2007-08 & -2.913 & -0.004 & $0.966(0.054)$ & 0.143 & 0.384 & 0.952 & 0.152 & 0.386 \\
\hline 2008-09 & -7.283 & -0.008 & $0.990(0.040)$ & 0.307 & 0.659 & 0.971 & 0.266 & 0.651 \\
\hline \multicolumn{9}{|l|}{ Mahela } \\
\hline 2006-07 & -7.927 & -0.005 & $0.986(0.044)$ & 0.407 & 0.567 & 0.926 & 0.329 & 0.404 \\
\hline $2007-08$ & -3.725 & -0.005 & $0.986(0.039)$ & 0.225 & 0.645 & 0.982 & 0.232 & 0.659 \\
\hline \multicolumn{9}{|l|}{ Portsgate } \\
\hline 2007-08 & -4.057 & -0.006 & $0.952(0.077)$ & 0.251 & 0.496 & 0.971 & 0.265 & 0.546 \\
\hline 2008-09 & -8.996 & -0.005 & $0.992(0.034)$ & 0.231 & 0.592 & 0.893 & 0.141 & 0.316 \\
\hline
\end{tabular}

a Peak prediction = Pearson's correlation between actual and predicted ascospore peaks (daily or 7-day accumulation in PAT); RMSE $=$ root-mean-square error. 
seasonal ascospore release (PAT < 0.05), which supports the earlier findings $(11,19)$.

The requisite effect of mild temperatures on pseudothecium maturation was observed and onset of ascospore release was delayed in cooler climates $(12,13)$. This observation was supported from analysis of DDtemp data-specifically, the low variation observed between data sets-which was also indicative of this parameter's suitability as predictor of pseudothecium maturation.

Two Gompertz models were selected from the various degreeday parameters to most accurately predict onset of ascospore release. The model using DDtemp as sole parameter (T-model) was the simplest but, based on inclusion of moisture parameters, the T/M-model using DDtemp, DDvpd, and DDrain should theoretically more accurately describe G. citricarpa pseudothecium maturation $(10,12,13,19)$. However, both models performed equally, especially when considering that first ascospore discharge was mostly predicted during the observed lag phases. Predictions were similar and the T/M-model differed largely due to the delayed prediction observed following a marked increase in DDrain. Excessive wetting was reported to be detrimental to pseudothecium maturation and ascospore release $(10,13)$. However, the T/M-model needs to be more extensively tested before complimenting its predictive ability in this regard. Rossi et al. (29) found DDwet to be the best predictor for onset of $V$. pirina ascospore release in a logistic regression model. This model infers that onset of ascospore release would be earlier in more moist seasons, which is contrary to what was predicted by the T/Mmodel on observed data sets. For M. citri, Mondal and Timmer
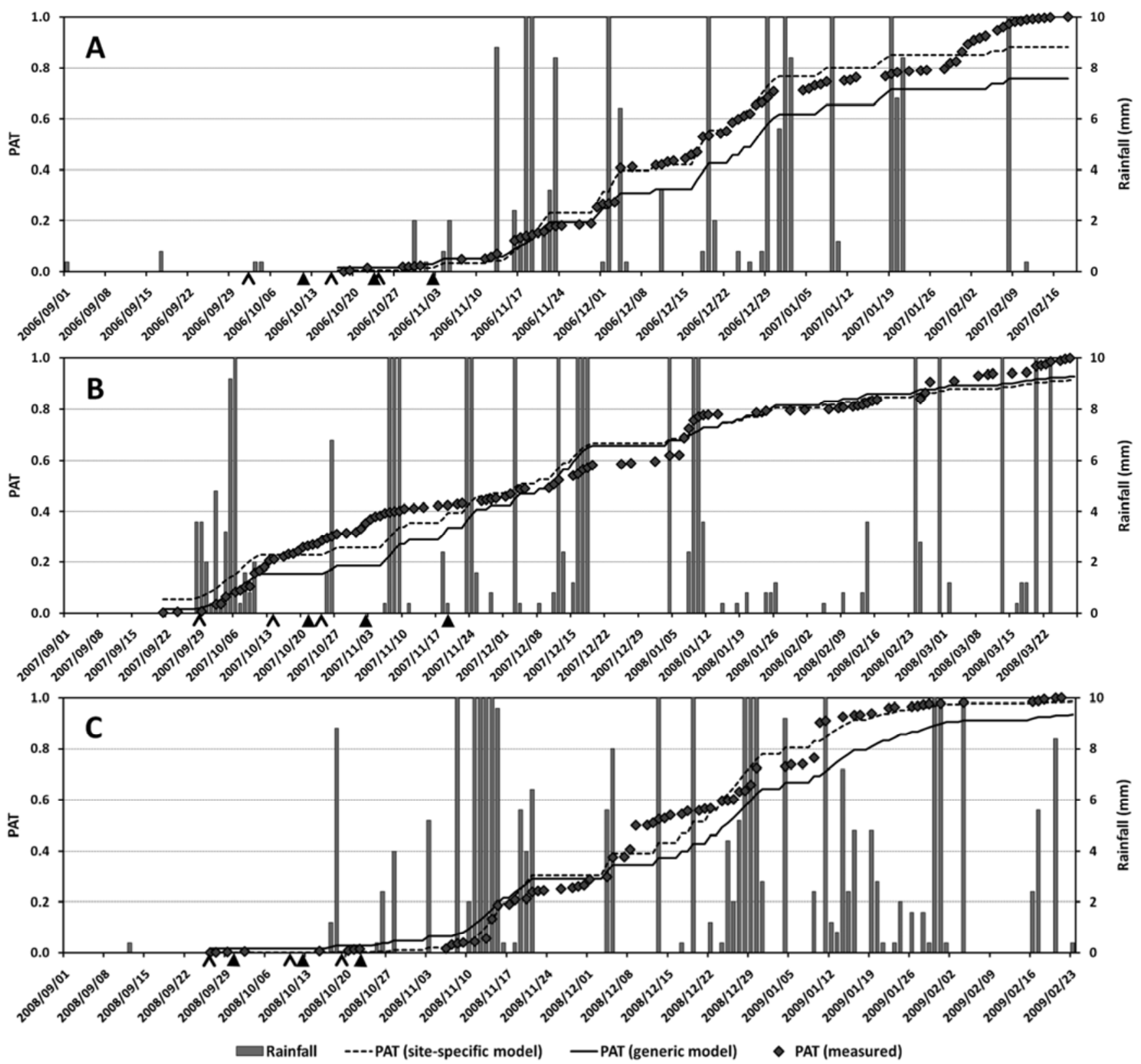

Fig. 2. Daily rainfall (shown up to $10 \mathrm{~mm}$ ), proportion of Guignardia ascospores trapped (PAT measured), and predicted PAT from degree-days $\left(>10^{\circ} \mathrm{C}\right)$ accumulated from the first seasonal ascospore discharge only on days with measurable rainfall $(>0.1 \mathrm{~mm}$ ) or vapor pressure deficit $<5 \mathrm{hPa}$ (DDwet2) using a generic Gompertz model [PAT (generic model) $=\exp (-4.096 \times \exp (-0.005 \times$ DDwet2); solid lines], as well as Gompertz models specifically for each locality-season combination [PAT (site-specific model); broken lines] at Letaba Oranje during the A, 2006-07; B, 2007-08; and C, 2008-09 seasons. Onset of ascospore release as predicted by probabilities of $0.5,0 ., 7$ and 0.8 using the temperature $(\boldsymbol{\Lambda}$; Event $=\exp [-\exp (-(-2.725+0.004 \times$ DDtemp $))])$ and temperature/moisture $(\boldsymbol{\Lambda}$; Event $=\exp [-\exp (-(-3.238+0.008 \times$ DDvpd $+0.004 \times$ DDtemp $-0.009 \times$ DDrain $))])$ models are indicated on the X-axes. DDtemp $=$ accumulated degree-days $\left({ }^{\circ} \mathrm{C}\right)$ using 1 July as biofix and $10^{\circ} \mathrm{C}$ as base temperature, DDvpd $=$ DDtemp accumulation only on days with vapor pressure deficit $<5 \mathrm{hPa}$, and DDrain $=$ DDtemp accumulation only on days with measurable rainfall $(>0.1 \mathrm{~mm})$. 
(23) demonstrated that pseudothecium maturation was accelerated at optimal temperatures $\left(\approx 28^{\circ} \mathrm{C}\right)$ and moderate duration and frequency of wetting. By increasing wetness, pseudothecium maturation was advanced but fewer ascospores were produced, probably due to accelerated leaf degradation.

By using the simpler T-model for Guignardia pseudothecium maturation, onset of ascospore release for various citrus-growing localities could be predicted from long-term weather data, being 767.9 to $933.0^{\circ} \mathrm{C}$ DDtemp (probabilities of 0.5 and 0.7 ), which were equivalent to the mean first and fifth percentile in the studied data sets. First discharge was accurately predicted for South African localities where CBS does occur (Letsitele [Limpopo province]; Nelspruit [Mpumalanga province]; and Kirkwood, Addo, and Patensie [Eastern Cape province]) based on actual spore trapping results (11; this study, as well as unpublished spore trapping results from Addo). However, these predictions were $\approx 2$ weeks earlier than the first "significant" releases reported by McOnie $(19,20)$ and Kotzé (12) for Nelspruit and Letsitele, respectively. This difference can most likely be attributed to the lag phase observed in a typical seasonal ascospore release pattern or, possibly, due to less sensitive spore trapping by the earlier studies. For Campinas in Brazil, onset of ascospore release was predicted for mid- to end of September, which agrees with earlier reports from Brazil (26). Predicted first discharge in Florida, notably in counties other than where CBS has recently been detected (http://www.pestalert.org/oprDetail.cfm?oprID=421), was similar to periods predicted for Letsitele and Nelspruit. Recent Guignardia ascospore trappings in Florida indicate that release occurs 1 month earlier than the dates predicted by the model (M. Dewdney, personal communication), which shows that the model could be improved by the inclusion of data from wetter and warmer localities. For CBS-absent localities, Citrusdal, Stellenbosch (Western Cape province, South Africa), Valencia (Spain), Messina (Italy), Riverside (California), and Pontecagnano (Italy), ascospore release is predicted to start in late spring to early summer only. Under these Mediterranean-type climates, the result would be that the bulk of ascospores would most likely be released during the dry summer months. These findings contradict reports stating the marginal suitability of these European localities for establishment of $G$. citricarpa $(4,5,36)$.

In the presented study, dates of first ascospore release as well as the numbers of ascospores trapped per season differed markedly between seasons and localities. Ascospore density was similar to that described by McOnie (19), as were seasonal peaks in ascospore release (events and density) $(19,20)$; the latter occurred in January, December, November, February, and October, in descending order. Interestingly, more events were recorded in October than February but ascospore density was lower. This might be indicative of the fairly uniform maturation of pseudothecia during spring $(11,19,20)$ and, possibly, of a decline in the number of viable pseudothecia during late summer.

Ascospores were trapped throughout the day and night, and a tendency was observed for more frequent and greater ascospore numbers released during 1200 to $2100 \mathrm{~h}$. This is in contrast to $V$. inaequalis, where ascospore release was definitely linked to daylight (15). Ascospore release during afternoons and evenings

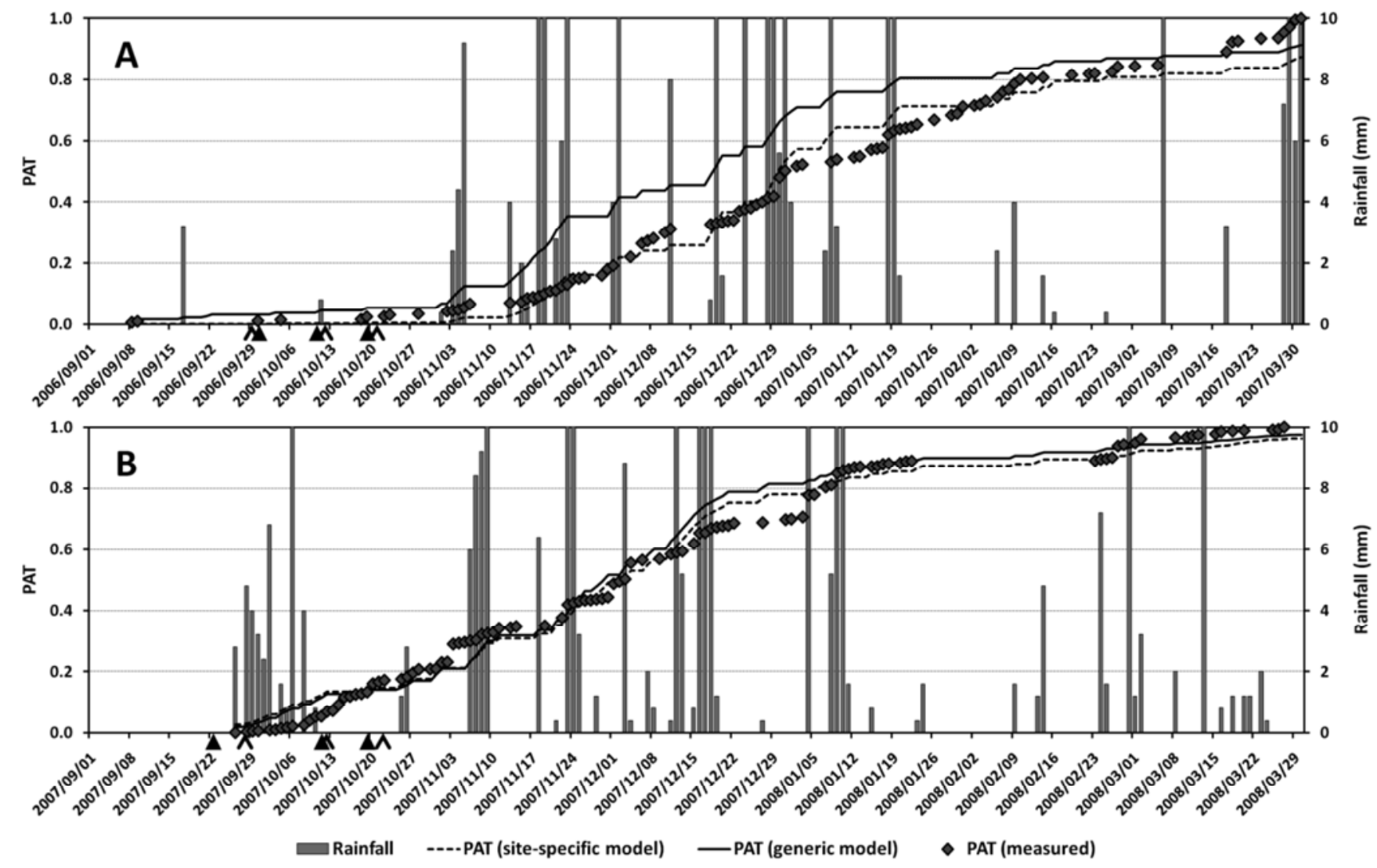

Fig. 3. Daily rainfall (shown up to $10 \mathrm{~mm}$ ), proportion of Guignardia ascospores trapped (PAT measured), and predicted PAT from degree-days $\left(>10^{\circ} \mathrm{C}\right.$ ) accumulated from the first seasonal ascospore discharge only on days with measurable rainfall $(>0.1 \mathrm{~mm}$ ) or vapor pressure deficit $<5 \mathrm{hPa}$ (DDwet2) using a generic Gompertz model [PAT (generic model $)=\exp (-4.096 \times \exp (-0.005 \times$ DDwet2); solid lines], as well as Gompertz models specifically for each locality-season combination [PAT (site-specific model); broken lines] at Mahela during the A, 2006-07 and B, 2007-08 seasons. Onset of ascospore release as predicted by probabilities of 0.5, 0.7 , and 0.8 using the temperature $(\boldsymbol{\Lambda}$; Event $=\exp [-\exp (-(-2.725+0.004 \times$ DDtemp $))])$ and temperature/moisture $(\boldsymbol{\Lambda} ; \operatorname{Event}=\exp [-\exp (-(-3.238+0.008 \times$ DDvpd $+0.004 \times$ DDtemp $-0.009 \times$ DDrain) $)]$ ) models are indicated on the $\mathrm{X}$-axes. DDtemp $=$ accumulated degree-days $\left({ }^{\circ} \mathrm{C}\right)$ using $1 \mathrm{July}$ as biofix and $10^{\circ} \mathrm{C}$ as base temperature, DDvpd $=$ DDtemp accumulation only on days with vapor pressure deficit $<5 \mathrm{hPa}$, and DDrain $=$ DDtemp accumulation only on days with measurable rainfall $(>0.1 \mathrm{~mm})$. 
might be linked to the frequent afternoon rain showers often experienced in the Limpopo province. However, rainfall infrequently coincided with ascospore events $(15.7 \%)$ or ascospore days $(38.3 \%)$, whereas rainfall was measured in the 3- and 7-day period leading up to 62.4 to $81.6 \%$ of ascospore release, respectively. Analysis of more significant ascospore events and days only ( $>120$ spores $/ \mathrm{m}^{3}$ trapped) showed a higher association with rainfall, although it was by no means exclusive (25.9 and $46.9 \%$, respectively). This is in contrast with earlier reports. Kotzé (11, 12) stated that ascospores were only released during rain spells, while McOnie (19) observed that ascospore release typically followed rains and that most ascospores were trapped during months with the highest rainfall. Lee and Huang (13) observed large quantities of ascospores released after rainfall, whereas small quantities were discharged under rainless conditions. These authors also noted higher numbers of spores trapped during nights than days. Although rain was required for initial and subsequent ascospore release in $M$. citri, spores were trapped on rainless days, demonstrating that other moisture factors such as irrigation, dew, and RH might be involved $(9,22)$.

From our study, we observed that most ascospores $(>75 \%)$ were released during 3 -h periods with high humidity $(>60 \% \mathrm{RH})$. Similarity in descriptive statistics for $\mathrm{RH}$ across data sets indicates its potential as predictor, possibly for conditions that trigger ascospore release, as was suggested for $M$. citri (22). This, however, needs to be investigated further.

Reis et al. (26) conducted Guignardia ascospore trapping in citrus orchards but spore trapping was restricted to one season and two orchards and commenced in late-spring only. These authors also found a poor linear correlation between ascospore release and temperature, rainfall (amount), and leaf wetness; leaf wetness was shown to be the most significant parameter. In the present study, no meaningful linear relation between ascospore release and the various weather parameters (temperature, rainfall, $\mathrm{RH}$, and VPD) could be discerned; leaf wetness was not included and could not be accurately modeled from mesoclimatic weather data.

Anecdotal evidence following years of commercial ascospore trapping has suggested temperature thresholds of 18 to $30^{\circ} \mathrm{C}$ for Guignardia ascospore release, although Kotzé (11) reported some ascospore release at low temperatures $\left(5^{\circ} \mathrm{C}\right)$ in a laboratory study. Empirical evidence from 2,000 ascospore events support these observations, because $90 \%$ of events occurred at 17.8 to $33.0^{\circ} \mathrm{C}$. Interestingly, Wager (37) reported $G$. citricarpa to be inactive in fruit rinds at temperatures $<18.5^{\circ} \mathrm{C}$, while $17^{\circ} \mathrm{C}$ was also found to be the best low-temperature threshold for accurate CLIMEX modeling of $G$. citricarpa $(25,39)$. Quantile estimation for daily temperatures on ascospore days yielded markedly lower $\mathrm{T}_{\min }$ values, with the 5 th and 25 th percentiles at 15.1 and $18.1^{\circ} \mathrm{C}$, respectively. These conditions are not optimal for infection, and longer wetness periods would be required to allow germination $(11,21)$.

A Gompertz model was most suitable to predict seasonal ascospore release. Models with the sole variables DDtemp2 or DDwet2, using the date of first seasonal ascospore trapping as biofix, gave similar goodness-of-fit statistics; however, the DDwet2 model was selected given its superior $R^{2}$ value. The

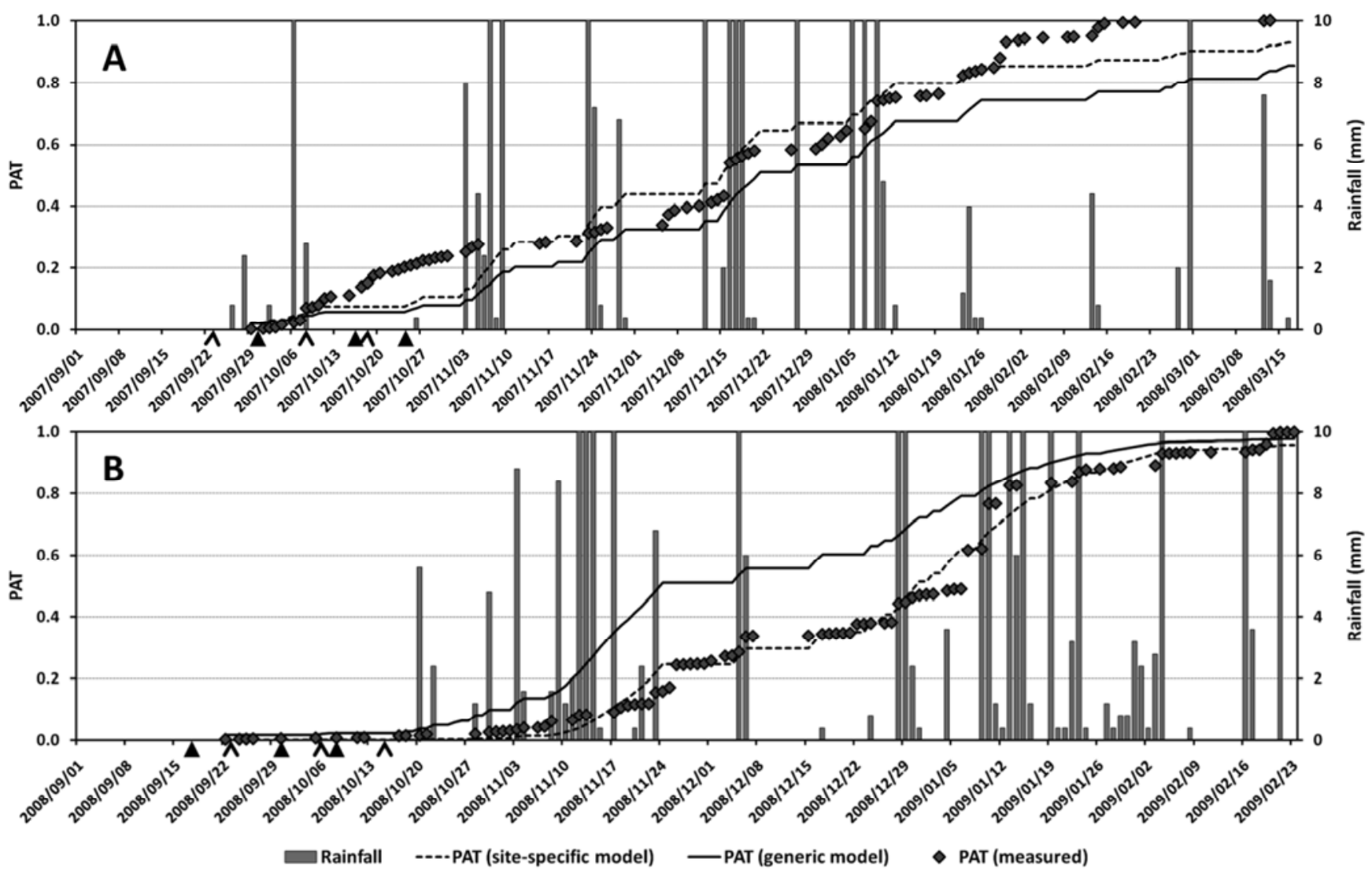

Fig. 4. Daily rainfall (shown up to $10 \mathrm{~mm}$ ), proportion of Guignardia ascospores trapped (PAT measured) and predicted PAT from degree-day days $\left(>10^{\circ} \mathrm{C}\right)$ accumulated from the first seasonal ascospore discharge only on days with measurable rainfall $(>0.1 \mathrm{~mm}$ ) or vapor pressure deficit $<5 \mathrm{hPa}$ (DDwet2) using a generic Gompertz model [PAT (generic model $)=\exp (-4.096 \times \exp (-0.005 \times$ DDwet2); solid lines], as well as Gompertz models specifically for each locality-season combination [PAT (site-specific model); broken lines] at Portsgate during the A, 2007-08 and B. 2008-09 seasons. Onset of ascospore release as predicted by probabilities of $0.5,0.7$, and 0.8 using the temperature $(\boldsymbol{\Lambda} ; \operatorname{Event}=\exp [-\exp (-(-2.725+0.004 \times$ DDtemp $))])$ and temperature/moisture $(\boldsymbol{\Delta} ; \operatorname{Event}=\exp [-\exp (-(-3.238+0.008 \times$ DDvpd $+0.004 \times$ DDtemp $-0.009 \times$ DDrain) $)]$ ) models are indicated on the $\mathrm{X}$-axes. DDtemp $=$ accumulated degree-days $\left({ }^{\circ} \mathrm{C}\right)$ using $1 \mathrm{July}$ as biofix and $10^{\circ} \mathrm{C}$ as base temperature, DDvpd $=$ DDtemp accumulation only on days with vapor pressure deficit $<5 \mathrm{hPa}$, and DDrain $=$ DDtemp accumulation only on days with measurable rainfall $(>0.1 \mathrm{~mm})$. 
DDtemp2 model adequately demonstrated the trend in ascospore release but, given the consistent and linear increase in DDtemp2, this model was unable to predict periods without or with peaks in ascospore release (results not shown). Following onset of ascospore release, actual spore release occurred fairly consistently, with few periods without release or with peaks in release. The DDwet2 model proved to be fairly accurate in predicting the lag phases, general trend, as well as 7-day peaks in ascospore release. In some cases, however, lag phases or significant peaks were not accurately predicted by either the generic or the site-specific models. In most seasons, Guignardia spores were trapped until shortly before the last seasonal trapping day (19 February to 2 April), indicating that spore discharge most likely continued thereafter. PAT was calculated from the total number of spores trapped per season, which might have overpredicted the onset of the upper asymptote of the PAT-predicting DDwet2 model.

The Guignardia DDwet2 model was similar to the ascospore release model for $V$. pirina (29). Despite the difference in calculation of the degree-days (10 instead of $0^{\circ} \mathrm{C}$ used as base temperature for the Guignardia model), most notable differences were in the model parameters. For $V$. pirina, the predicted lag phase varied considerably between cases, as well as the slope of the inflection point. The latter was often steeper compared with that predicted for the Guignardia model, which might be indicative of a longer ascospore release period for Guignardia spp. As for the V. pirina model, the lag phase was influenced by wetness and was longer in drier conditions. However, the lag phases predicted for Guignardia spp. were generally longer (10 to 70 days) than those predicted for V. pirina (10 to 21 days).

Potential application of the Guignardia pseudothecium maturation models would be to predict onset of ascospore release in climatically diverse citrus-growing regions. Preventative fungicide sprays are essential for effective CBS control, and these models would be useful in predicting timing of these sprays. Provided with reliably predicted weather parameters (rainfall, $\mathrm{RH}$, and temperature), duration of lag phases and 7-day peaks in ascospore release could be predicted by the seasonal ascospore release model. This will provide growers with a decision support tool; for example, in determination of spray intervals or specific fungicides to be used. The practical implementation of these models as decision support tools will be evaluated further, as well as refinement by inclusion of microclimatic weather data and, most importantly, by specific identification and quantification of proportion of $G$. citricarpa ascospores trapped.

\section{ACKNOWLEDGMENTS}

We thank Citrus Research International, Thrip and QMS Agri Science for financial support, M. van der Rijst (ARC-Biomet, Stellenbosch, South Africa) for biometrical support, and J. M. Kotzé for critical review of the manuscript.

\section{LITERATURE CITED}

1. Baayen, R. P., Bonants, P. J. M., Verkley, G., Carroll, G. C., van der Aa, H. A., de Weerdt, M., van Brouwershaven, I. R., Schutte, G. C., Maccheroni W., de Blanco, C. G., and Azevedo, J. L. 2002. Nonpathogenic isolates of the citrus black spot fungus, Guignardia citricarpa, identified as a cosmopolitan endophyte of woody plants, G. mangiferae (Phyllosticta capitalensis). Phytopathology 92:464-477.

2. Baldassari, R. B., Wickert, E., and de Goes, A. 2008. Pathogenicity, colony morphology and diversity of isolates of Guignardia citricarpa and G. mangiferae isolated from Citrus spp. Eur. J Plant Pathol. 120:103-110.

3. Durán, E. L., Ploper, L. D., Ramallo, J. C., Piccolo Grandi, R. A., Hupper Giancoli, Á. C., and Azevedo, J. L. 2005. The foliar fungal endophytes of Citrus limon in Argentina. Can. J. Bot. 83:350-355.

4. EFSA, 2008. Scientific opinion of the panel on plant health on a request from the European commission on Guignardia citricarpa Kiely. EFSA J. 925:1-108.

5. EFSA, 2008. Appendix to scientific opinion of the panel on plant health on a request from the European commission on Guignardia citricarpa
Kiely. EFSA J. 925:Appendix 1-45.

6. Gadoury, D. M., and MacHardy, W. E. 1982. A model to estimate the maturity of ascospores of Venturia inaequalis. Phytopathology 72:901-904.

7. Glienke, C., Pereira, O. L., Stringari, D., Fabris J., Kava-Cordeiro, V., Galli-Terasawa, L., Cunnington, J., Shivas, R. G., Groenewald, J. Z., and Crous, P. W. 2011. Endophytic and pathogenic Phyllosticta species, with reference to those associated with citrus black spot. Persoonia 26:47-56.

8. Glienke-Blanco, C., Aguilar-Vildoso, C. I., Carneiro Vieira, M. L., Vianna Barroso, P. A., and Azevedo, J. L. 2002. Genetic variability in the endophytic fungus Guignardia citricarpa isolated from citrus plants. Genet. Mol. Biol. 25:251-255.

9. Hidalgo, H., Sutton, T. B., and Arauz, F. 1997. Epidemiology and control of citrus greasy spot on Valencia orange in the humid tropics of Costa Rica. Plant Dis. 81:1015-1022.

10. Kiely, T. B. 1948. Preliminary studies on Guignardia citricarpa n. sp., the ascigerous stage of Phoma citricarpa McAlp., and its relation to blackspot of citrus. Proc. Linn. Soc. N.S.W. 73:249-292.

11. Kotzé, J. M., 1963. Studies on the black spot disease of citrus caused by Guignardia citricarpa Kiely, with particular reference to its epiphytology and control at Letaba. D.Sc. (Agric.) thesis, University of Pretoria, South Africa.

12. Kotzé, J. M., 1981. Epidemiology and control of citrus black spot in South Africa. Plant Dis. 65:945-950.

13. Lee, Y. S., and Huang, C. S. 1973. Effect of climatic factors on the development and discharge of ascospores of the citrus black spot fungus. J. Taiwan Agric. Res. 22:135-144.

14. Lovell, D. J., Powers, S. J., Welham, S. J., and Parker, S. R., 2004. A perspective on the measurement of time in plant disease epidemiology. Plant Pathol. 53:705-712.

15. MacHardy, W. E., and Gadoury, D. M. 1986. Patterns of ascospore discharge by Venturia inaequalis. Phytopathology 76:985-990.

16. Madden, L. V. 2006. Botanical epidemiology: some key advances and its continuing role in disease management. Eur. J. Plant Pathol. 115:3-23.

17. McOnie, K. C. 1964. Apparent absence of Guignardia citricarpa Kiely from localities where citrus black spot is absent. S. Afr. J. Agric. Sci. 7:347-354

18. McOnie, K. C. 1964. The latent occurrence in citrus and other hosts of a Guignardia easily confused with G. citricarpa, the citrus black spot pathogen. Phytopathology 54:40-43.

19. McOnie, K. C. 1964. Orchard development and discharge of ascospores of Guignardia citricarpa and the onset of infection in relation to the control of citrus black spot. Phytopathology 54:1148-1453.

20. McOnie, K. C. 1964. Source of inoculum of Guignardia citricarpa, the citrus black spot pathogen. Phytopathology 54:64-67.

21. McOnie, K. C. 1967. Germination and infection of citrus by ascospores of Guignardia citricarpa in relation to control of black spot. Phytopathology 57:743-746.

22. Mondal, S. N., Gottwald, T. R., and Timmer, L. W. 2003. Environmental factors affecting the release and dispersal of ascospores of Mycosphaerella citri. Phytopathology 93:1031-1036.

23. Mondal, S. N., and Timmer, L. W. 2002. Environmental factors affecting pseudothecial development and ascospore production of Mycosphaerella citri, the cause of citrus greasy spot. Phytopathology 92:1267-1275.

24. Nagelkerke, N. J. D. 1991. A note on a general definition of the coefficient of determination. Biometrika 78:691-692.

25. Paul, I., van Jaarsveld, A. S., Korsten, L., and Hattingh, V. 2005. The potential global geographical distribution of citrus black spot caused by Guignardia citricarpa Kiely: likelihood of disease establishment in the European Union. Crop Prot. 24:297-308.

26. Reis, R. F., Timmer, L. W., and de Goes, A. 2006. Effect of temperature, leaf wetness and rainfall on the production of Guignardia citricarpa ascospores and on black spot severity on sweet orange. Fitopatol. Bras. 31:29-34.

27. Rossi, V., Ponti, I., Marinelli, M., Giosuè, S., and Bugiani, R. 1999. Field evaluation of some models estimating the seasonal pattern of airborne ascospores of Venturia inaequalis. J. Phytopathol. 147:567-575.

28. Rossi, V., Ponti, I., Marinelli, M., Giosuè, S., and Bugiani, R. 2001. Environmental factors influencing the dispersal of Venturia inaequalis ascospores in the orchard air. J. Phytopathol. 149:11-19.

29. Rossi, V., Salinari, F., Pattori, E., Giosuè, S., and Bugiani, R. 2009. Predicting the dynamics of ascospore maturation of Venturia pirina based on environmental factors. Phytopathology 99:453-461.

30. Schutte, G. C., Beeton, K. V., and Kotzé, J. M. 1997. Rind stippling on Valencia oranges by copper fungicides used for control of citrus black spot in South Africa. Plant Dis. 81:851-854.

31. Schutte, G. C., Mansfield, R. I., Smith, H., and Beeton, K. V. 2003. Application of azoxystrobin for control of benomyl-resistant Guignardia citricarpa on 'Valencia' oranges in South Africa. Plant Dis. 87:784-788.

32. Schutte, G. C., Tollig, B., Mansfield, R. I., and Kotzé, J. M. 1996. Effect of kresoxim-methyl and azoxystrobin for the control of a benzimidazole 
resistant strain of citrus black spot. Proc. Int. Soc. Citric. 8:345-350.

33. Schwarz, G. E. 1978. Estimating the dimension of a model. Ann. Stat. 6:461-464.

34. Spósito, M. B., Amorim, L., Ribeiro, P. J., Jr., Bassanezi, R. B., and Krainski, E. T. 2007. Spatial pattern of trees affected by black spot in citrus groves in Brazil. Plant Dis. 91:36-40.

35. Sutton, B. C., and Waterston, J. M. 1966. Guignardia citricarpa. Descriptions of Pathogenic Fungi and Bacteria, Number 85. CAB International, Wallingford, UK.

36. Vicent, A., and García-Jiménez, J. 2008. Risk of establishment of nonindigenous diseases of Citrus fruit and foliage in Spain: An approach using meteorological databases and tree canopy climate data. Phytoparasitica 36:7-19.

37. Wager, V. A. 1952. The black spot disease of citrus in South Africa. Sci. Bull. No. 303. Department of Agriculture, Union of South Africa, Pretoria.

38. Yin, X. Y., Kropff, M. J., McLaren, G., and Visperas, R. M. 1995. A nonlinear model for crop development as a function of temperature. Agric. For. Meteorol. 77:1-16.

39. Yonow, T., Hattingh, V., and de Villiers, M. 1013. CLIMEX modelling of the potential global distribution of the citrus black spot disease caused by Guignardia citricarpa and the risk posed to Europe. Crop Prot. 44:18-28. 